BRUM, D; MARCHI, PM; GONÇALVES, MA; CRUZ, FF; ANTUNES, LEC; GOMES, CB. 2019. Reaction of strawberry cultivars to root-knot and rootlesion nematodes. Horticultura Brasileira 37: 065-068. d DOI - http://dx.doi.org/10.1590/S0102-053620190110

\title{
Reaction of strawberry cultivars to root-knot and root-lesion nematodes
}

\section{Daniele de Brum ${ }^{1} \mathbb{D}$; Priscila Monalisa Marchi ${ }^{2} \mathbb{D}$; Michel A Gonçalves ${ }^{3} \mathbb{D}$; Fernanda F Cruz ${ }^{4} \mathbb{D}$; Luis Eduardo C Antunes ${ }^{2} \mathbb{D}$; Cesar B Gomes ${ }^{2} \mathbb{D}$}

${ }^{1}$ Universidade Federal de Pelotas (UFPel), Pelotas-RS, Brazil; missiodani@hotmail.com; ${ }^{2}$ Embrapa Clima Temperado, Pelotas-RS, Brazil; cesar.gomes@embrapa.br; priscilammarchi@yahoo.com.br; ${ }^{3}$ Prefeitura Municipal de Canguçu, Canguçu-RS, Brazil; aldrighimichel@gmail. com; ${ }^{4}$ Universidad Miguel Hernández de Elche, Elche, Spain; fernanda.ferreiracruz@gmail.com; luis.antunes@embrapa.br

\begin{abstract}
Considering the economic importance of strawberry in Brazil, with a clear migration trend from the soil to innovative systems on substrates, it is fundamental to evaluate the available cultivars in the market regarding tolerance to pathogens with potential for infestation. The reaction of eight commercial strawberry cultivars (Festival, Camino Real, Camarosa, Oso Grande, Monterey, San Andreas, Aromas, and Albion) to Meloidogyne and Pratylenchus species was evaluated. Strawberry cultivars were maintained in individual pots with sterilized soil and inoculated with 5,000 eggs + second stage juveniles of Meloidogyne arenaria, M. incognita, M. javanica or M. hapla or 1,000 specimens of Pratylenchus zea or P. brachyurus per plant. The experiment was carried out in a completely randomized design with six replications using tomato 'Rutgers' and sorghum ' 506 ' plants as control to root-knot and lesion nematodes, respectively. Ninety days after inoculation, the nematode reproduction factor $(\mathrm{RF}=$ final population/initial population) was evaluated to determine the resistance of the strawberry genotypes to each nematode species. All cultivars behaved as resistant $(\mathrm{FR}<1.00)$ or immune $(\mathrm{FR}=0.00)$ to M. javanica, $M$. incognita, $P$. zeae and $P$. brachyurus. The cultivar 'Camarosa' was susceptible (FR>1.00) to M. arenaria and M. hapla and 'Oso Grande' behaved as a good host to M. hapla; however, the other cultivars were resistant to these two Meloidogyne species. The assessed cultivars are poor hosts, being an alternative to be used in infested areas with these pests.
\end{abstract}

Keywords: Fragaria x ananassa, Meloidogyne spp., Pratylenchus spp., resistance.

\section{RESUMO}

Reação de cultivares de morangueiro ao nematoide das galhas e das lesões

Considerando a importância econômica da cultura do morangueiro no Brasil, com tendência clara de migração da produção no solo para sistemas inovadores de produção em substratos, é fundamental a avaliação das cultivares disponíveis no mercado quanto a tolerância a patógenos com potencial de infestação. Avaliou-se a resistência de oito cultivares comerciais (Festival, Camino Real, Camarosa, Oso Grande, Monterey, San Andreas, Aromas e Albion) a espécies de Meloidogyne e Pratylenchus. Cultivares de morango, mantidas em vasos individuais com solo esterilizado, foram inoculadas com 5.000 ovos + juvenis de segundo estágio de Meloidogyne arenaria, M. incognita, M. javanica ou M. hapla ou 1.000 espécimes de Pratylenchus zea ou P. brachyurus por planta. O experimento foi conduzido sob condições de casa de vegetação em delineamento inteiramente casualizado com seis repetições, utilizando-se plantas de sorgo '506' e tomate 'Rutgers' como controles para o nematoides das galhas e das lesões radiculares, respectivamente. Noventa dias após a inoculação, foi avaliado o fator de reprodução dos nematoides (RF = população final / população inicial) para determinar a resistência dos genótipos de morango a cada espécie de fitonematoide. Todas as cultivares se comportaram como resistentes $(\mathrm{FR}<1,00)$ ou imunes $(\mathrm{FR}=0,00)$ a $M$. javanica, M. incognita, . zeae e P. brachyurus. Apenas 'Camarosa' foi suscetível $(\mathrm{FR}>1,00)$ a $M$. arenaria e $M$. hapla e 'Oso Grande' comportou-se como suscetível a M. hapla; porém, as demais cultivares foram resistentes a estas duas espécies do nematoide das galhas. As cultivares de morango avaliadas neste trabalho comportaram-se como más hospedeiras dos nematoides estudados e, podem ser consideradas alternativa de cultivo em áreas infestadas com os patógenos.

Palavras-chave: Fragaria $x$ ananassa, Meloidogyne spp., Pratylenchus spp., resistência.

\section{Received on August 2, 2018; accepted on January 24, 2019}

$\mathrm{T}$ he strawberry (Fragaria x ananassa) has great economic and social importance in the United States, Mexico, Turkey, Poland, Italy, Germany, Russia, including Latin American countries as Chile and Brazil (Coelho Júnior, 2016; OMAIAA, 2017). There are around 4,200 ha of strawberry cultivated areas in Brazil, and the principal producing states are Minas Gerais, Paraná and Rio Grande do Sul (Fagherazzi et al., 2017).

New information on the health benefits of strawberries, such as antioxidant levels, folate, potassium, vitamin $\mathrm{C}$ and fiber content, stimulated consumption rates (Garcia et al.,
2017). Despite the high added value of the product, broad acceptance by consumers and diversity in the marketing (Fachinello et al., 2011), this crop has a relevant social role in the family farming (Antunes et al., 2007; Lemiska et al., 2014).

The main strawberry production 
system in Brazil is based on growing under low tunnel(Fagherazzi et al., 2017). Therefore, this crop may be affected by many soil pathogens such as the plant parasitic nematodes Meloidogyne spp. and Pratylenchus spp. (Maas, 1998; Gomes \& Cofcewics, 2003). Rootknot nematodes (Meloidogyne spp.) are polyphagous pests and cause great damage in several annual and perennial crops associated to yield losses (Sharma \& Fonseca, 2000; Franzener et al., 2005; Lima-Medina et al., 2014). Similarly, root-lesion nematodes (Pratylenchus spp.), the second most important plantparasitic nematode group for Brazilian agriculture, parasites various crops such as soybeans, oats, corn, millet, sunflower, sugarcane, fruit trees besides other common cultivated plant species (Severino et al., 2010; Ribeiro et al., 2010; Lima-Medina et al., 2014).

Among the control practices for these two plant-parasitic nematode genera, the use of resistant cultivars is one of the most suitable. However, for strawberry, few studies have been performed for Brazilian conditions. Curi et al. (2016) studied the reaction of some strawberry commercial cultivars to Meloidogyne hapla. The authors verified the genetic resistance of Oso Grande and Albion. Similarly, 'Camarosa' is resistant to $M$. enterolobii and M. ethiopica (Somavilla et al., 2006; Freitas et al., 2016) but the reaction of these cultivars to other Meloidgyne species and to Pratylenchus spp. in not known. Considering the pathogenicity of these pests and the scarcity of studies reported on the strawberry, the objective of this work was to evaluate the resistance of eight strawberry cultivars to Meloidogyne and Pratylenchus species related to tropical and subtropical conditions.

\section{MATERIAL AND METHODS}

The reaction of eight strawberry cultivars to four root-knot Meloidogyne species and two lesion Pratylenchus species was evaluated at greenhouse conditions. Strawberry seedlings of Festival, Monterrey, Camino Real, San Andreas, Camarosa, Oso Grande, Aromas and Albion cultivars obtained from tissue culture were used to establish this assay. The inoculum of the Meloidogyne and Pratylenchus species was obtained according to the methodology of Hussey \& Barker (1973) and Coolen \& D'Here (1972), respectively.

One pure population of $M$. javanica Est J3, M. arenaria Est A2, M. incognita Est $\mathrm{I} 2$ and M. hapla Est $\mathrm{H} 2$ were maintained on tomato plants (Solanum lycopersicum) cv. Rutgers at greenhouse conditions in order to use as root-knot nematode inoculum. Similarly, pure populations of Pratylenchus zeae and $P$. brachyurus were maintained on Sorghum bicolor '506' plants to use nematode inoculum.

Strawberry seedlings 30-day old, grown in pots with sterilized soil, were inoculated with 5,000 eggs + second stage juveniles of Meloidogyne arenaria, M. incognita, M. javanica or M. hapla or 1,000 Pratylenchus zeae or $P$. brachyurus per plant. The experiment was carried out under greenhouse conditions in a completely randomized design with six replications using tomato 'Rutgers' and sorghum '506' plants as controls to root-knot and root-lesion nematodes, respectively. A randomized design experiment with six replications of one plant per plot was used.

Ninety days after inoculation, each strawberry plant inoculated with rootknot nematode was evaluated for number of galls in the roots. Subsequently, each root system was processed (Hussey $\&$ Barker,1973) to determine the final nematode populations (number of eggs and second stage juveniles) in the different strawberry cultivars. However, to calculate the final population of Pratylenchus species, the roots of different plants were processed by Coolen \& D'Herde (1972) method. The reproduction factor $(\mathrm{RF}=$ final population / initial population) of each nematode species obtained in each genotype was estimated. Averages of the different variables were compared by Scott-Knott's clustering test at 5\% using the software SASM-Agri (Canteri et al., 2001). The strawberry reaction was determined by the nematode reproduction factor (RF), considering resistant genotypes with $\mathrm{RF}<1.00$, immune with $\mathrm{RF}=0.00$ and susceptible with RF>1.00 (Oostenbrik, 1966).

\section{RESULTS AND DISCUSSION}

Most cultivars were resistant or immune to various nematode species (Table 1). Only 'Camarosa' and 'Oso Grande' were susceptible to $M$. arenaria, and the first was susceptible to $M$. hapla as compared to the susceptible control. Furthermore, the presence of galls on the roots of plants inoculated with Meloidogyne spp. was detected principally of susceptible cultivars (Figure 1). All strawberry cultivars were resistant or immune to $P$. zeae and $P$. brachyurus (Table 1). This information is important, because Camarosa is the second most cultivated cultivar in Brazil mainly in soil system production.

In other studies, regarding strawberry genetic resistance to Meloidogyne spp., 'Camarosa', 'Oso Grande', 'Aromas', 'Camino Real', 'Santa Clara' and 'Ventana' were immune to M. enterolobii (Freitas et al., 2016) and the first three cultivars were resistant to $M$. ethiopica (Somavilla et al., 2006). Pinkerton \& Finn (2005), evaluating the reaction of more than 30 strawberry genotypes to M. hapla, observed that most cultivars were resistant to nematode including 'Camarosa', which in this study behaved as susceptible.

The reaction of strawberry to rootlesion nematodes observed in this assay was similar to those obtained in other studies with $P$. penetrans in the USA (Pinkerton \& Finn, 2005; Villanueva et al., 2010). The authors observed resistance and tolerance in more than 30 cultivars, including three genotypes evaluated in this experiment as Camarosa, Diamante and Festival. Once there is little information available on the genetic resistance of strawberry to tropical and subtropical Pratyenchus species (P. zeae and P. brachyurus) our results support the need to carry out additional studies on genetic resistance and aggressiveness, using different populations of phytoparasitic nematodes as noted by Loubser \& Meyer (1987) and Lima-Medina et al. (2017) in other pathosystems. 
Table 1. Reaction of strawberry cultivars to different root-knot (Meloidogyne spp.) and root-lesion (Pratylenchus spp.) species of nematodes. Pelotas, Embrapa Clima Temperado, 2018.

\begin{tabular}{|c|c|c|c|c|c|c|c|c|c|}
\hline \multirow{2}{*}{ Cultivars } & \multicolumn{3}{|c|}{ Meloidogyne incognita } & \multicolumn{3}{|c|}{ Meloidogyne arenaria } & \multicolumn{3}{|c|}{ Meloidogyne javanica } \\
\hline & galls $\left(n^{0}\right)$ & RF & $\mathbf{R}$ & galls $\left(n^{0}\right)$ & RF & $\mathbf{R}$ & galls $\left(n^{0}\right)$ & RF & $\mathbf{R}$ \\
\hline Control & 199.16 & 7.11 & $\mathrm{~S}^{1}$ & 352.66 & 16.33 & $\mathrm{~S}^{1}$ & 345 & 24.13 & $\mathrm{~S}^{1}$ \\
\hline Camarosa & $0.00^{\mathrm{ns}}$ & $0.00 a^{*}$ & I & $123.00 \mathrm{~b}$ & $2.82 \mathrm{c}$ & $\mathrm{S}$ & $0.00^{\mathrm{ns}}$ & $0.08 b$ & $\mathrm{R}$ \\
\hline Oso Grande & 0.00 & $0.00 \mathrm{a}$ & I & $105.00 \mathrm{~b}$ & $2.01 \mathrm{c}$ & $\mathrm{S}$ & 0.00 & $0.12 b$ & $\mathrm{R}$ \\
\hline Monterrey & 0.00 & $0.00 \mathrm{a}$ & I & $0.00 \mathrm{a}$ & $0.01 b$ & $\mathrm{R}$ & 0.00 & $0.04 \mathrm{~b}$ & $\mathrm{R}$ \\
\hline Festival & 0.00 & $0.00 \mathrm{a}$ & I & $0.00 \mathrm{a}$ & $0.02 b$ & $\mathrm{R}$ & 0.00 & $0.12 b$ & $\mathrm{R}$ \\
\hline San Andres & 0.00 & $0.21 b$ & $\mathrm{R}$ & $0.00 \mathrm{a}$ & $0.18 b$ & $\mathrm{R}$ & 0.00 & $0.12 b$ & $\mathrm{R}$ \\
\hline Aromas & 0.00 & $0.03 \mathrm{a}$ & $\mathrm{R}$ & $0.00 \mathrm{a}$ & $0.14 \mathrm{~b}$ & $\mathrm{R}$ & 0.00 & $0.12 b$ & $\mathrm{R}$ \\
\hline Camino Real & 0.00 & $0.00 \mathrm{a}$ & I & $7.00 \mathrm{c}$ & $0.11 b$ & $\mathrm{R}$ & 0.00 & $0.09 b$ & $\mathrm{R}$ \\
\hline Albion & 0.00 & $0.00 \mathrm{a}$ & $\mathrm{I}$ & $0.00 \mathrm{a}$ & $0.00 \mathrm{a}$ & I & 0.00 & $0.00 \mathrm{a}$ & I \\
\hline \multirow[t]{3}{*}{ CV (\%) } & - & 15.45 & & 21.55 & 16.23 & & - & 15.13 & \\
\hline & \multicolumn{4}{|c|}{ Meloidogyne hapla } & \multicolumn{2}{|c|}{ Pratylenchus zeae } & \multicolumn{3}{|c|}{ Pratylenchus brachyurus } \\
\hline & galls $\left(\mathrm{n}^{0}\right)$ & RF & & $\mathbf{R}$ & RF & $\mathbf{R}$ & & & $\mathbf{R}$ \\
\hline Control & 1150 & 24.39 & & $\mathrm{~S}^{1}$ & 9.41 & $\mathrm{~S}^{2}$ & 7.5 & & $\mathrm{~S}^{2}$ \\
\hline Camarosa & $15.00 \mathrm{~b}$ & $1.40 \mathrm{~b}$ & & $\mathrm{~S}$ & $0.88 \mathrm{a}$ & $\mathrm{R}$ & & & $\mathrm{R}$ \\
\hline Oso Grande & $0.00 \mathrm{a}$ & $0.10 \mathrm{a}$ & & $\mathrm{R}$ & $0.60 \mathrm{~b}$ & $\mathrm{R}$ & & & $\mathrm{R}$ \\
\hline Monterrey & $0.00 \mathrm{a}$ & $0.01 \mathrm{a}$ & & $\mathrm{R}$ & $0.00 \mathrm{c}$ & I & & & I \\
\hline Festival & $0.00 \mathrm{a}$ & $0.01 \mathrm{a}$ & & $\mathrm{R}$ & $0.61 b$ & $\mathrm{R}$ & & & I \\
\hline San Andres & $0.40 \mathrm{a}$ & $0.01 \mathrm{a}$ & & $\mathrm{R}$ & $0.00 \mathrm{c}$ & I & & & I \\
\hline Aromas & $0.00 \mathrm{a}$ & $0.17 \mathrm{a}$ & & $\mathrm{R}$ & $0.64 b$ & $\mathrm{R}$ & & & $\mathrm{R}$ \\
\hline Camino Real & $0.00 \mathrm{a}$ & $0.01 \mathrm{a}$ & & $\mathrm{R}$ & $0.00 \mathrm{c}$ & I & & & I \\
\hline Albion & $7.40 \mathrm{~b}$ & $0.25 \mathrm{a}$ & & $\mathrm{R}$ & $0.18 \mathrm{~b}$ & $\mathrm{R}$ & 0. & & $\mathrm{R}$ \\
\hline CV (\%) & 9.7 & 11.22 & & & 9.91 & & & & \\
\hline
\end{tabular}

Means followed by same letters in the column belong to the same group by Scott-Knott test, $5 \%$ probability. $1=$ tomato Rutgers control; $2=$ sorghum BRS 506 control; $\mathrm{R}=$ reaction; $\mathrm{RF}=$ reproduction factor; (immune with $\mathrm{RF}=0.00$ and susceptible with $\mathrm{RF}>1.00$ ) $\mathrm{S}=$ susceptible; $\mathrm{I}=$ immune; $\mathrm{R}=$ resistant.

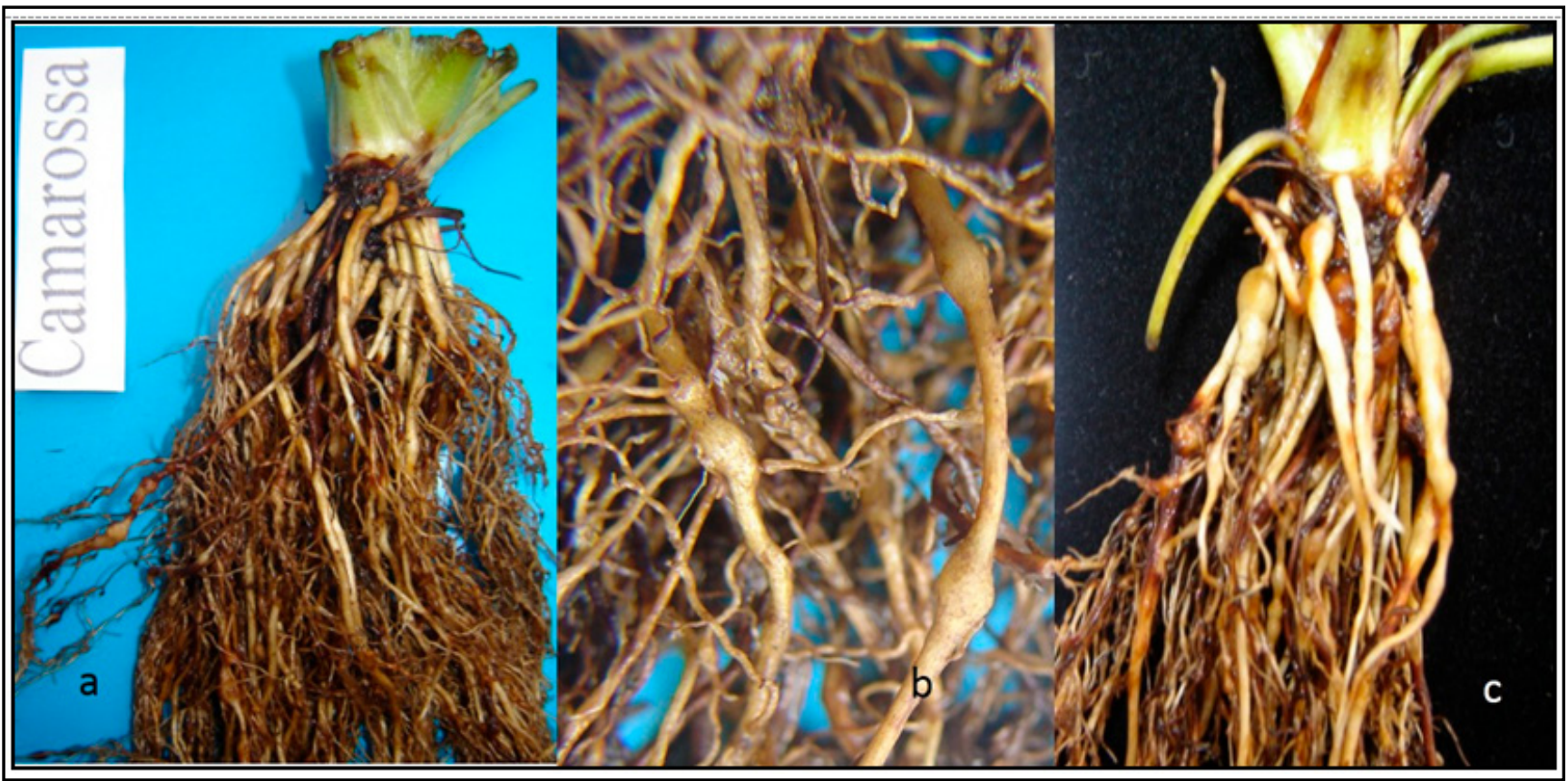

Figure 1. Root-systems of strawberry plants exhibiting galls caused by Meloidogyne arenaria (a) and M. hapla (b) at 'Camarosa' and M. arenaria at root-system of Oso Grande cultivar (c). Pelotas, Embrapa Clima Temperado, 2017. Foto: Cesar Bauer Gomes. 
Considering the most strawberry cultivars were poor hosts to different Meloidogyne and Pratylenchus species, these results are extremely important for establishing control strategies of these pests, suppressing their populations in the soil. Therefore, the use of resistant strawberry cultivars represents a viable alternative in the implementation of crop rotation systems to the management of these pests, becoming thus an efficient and economic way to reduce nematode populations in infested areas (Carneiro et al., 2000; Ferraz \& Freitas, 2004; Lima et al., 2009; Freitas et al., 2016).

Most of the evaluated strawberry cultivars (Festival, Monterrey, Camino Real, San Andreas, Aromas and Albion) are resistant or immune to Meloidogyne spp. and Pratylenchus spp. which confers their status as poor host. In this way these cultivars are an alternative to use in infested areas with these pests.

\section{REFERENCES}

ANTUNES, LEC; DUARTE, FJD; CALEGARIO, FF; COSTA, H; REISSER, JC. 2007. Produção integrada de morango no Brasil. Informe Agropecuário 38: 34-39.

CANTERI, MG; ALTHAUS, RA; VIRGENS FILHO, JS; GIGLIOTI, EA; GODOY, CV. 2001. SASM-AGRI: Sistema para análise e separação de médias em experimentos agrícolas pelos métodos Scott-Knott, Tukey e Duncan. Revista Brasileira de Agrocomputação 1: 18-24.

CARNEIRO, RMDG; RANDIG, O; ALMEIDA, MRA; CAMPOS, AD. 2000. Resistance of vegetable crops to Meloidogyne spp.: suggestion for a crop rotation. Nematologia Brasileira 24: 49-54.

COELHO JÚNIOR, JM. 2016. Strawberry cultivars: Knowing to expand and reduce the environmental impacts. Revista Geama 5: 138-147.

COOLEN, WA; D'HERDE, CJA. 1972. Method for the quantitative extraction of nematodes from plant tissue. Ghent: State Nematology and Entomology Research Station. 77p.

CURI, PN; PECHE, PM; PIO, R; CAPRONI, CM; OLIVEIRA, MS. 2016. Relationship between production, nematodes and redness; in strawberries. Ciência Rural 46: 1309-1315.

FACHINELLO, JC; PASA, MS; SCHMTIZ, JD; BETEMPS, DL. 2011. Situação e perspectivas da fruticultura de clima temperado no Brasil. Revista Brasileira de Fruticultura p.109-120. Available <http://www.scielo.br/pdf/rbf/v33 nspe1/a14v33nspe1.pdf. $>$ Accessed November 02, 2013.

FAGHERAZZI，AF; GRIMALDI, F; KRETZSCHMAR, AA; MOLINA, AR; GONÇALVES, MA; ANTUNES, LEC; BARUZZI, G; RUFATO, L. Strawberry production progress in Brazil. Acta Horticulturae. 1156:937-940, 2017. Available <http://www.actahort.org/ books/1156/1156_138.htm $>$ Accessed August 10, 2017.

FERRAZ, S; FREITAS, LG. 2004. Use of antagonistic plants and natural products. In: CHEN, Z; CHEN, S; DICKSON, DW (eds). Nematology: advances and perspectives. Beijing: Tsinghua University Press. p.931-978.

FRANZENER, G; UNFRIED, JR; STANGARLIN, JR; FURLANETO, C. 2005. Nematoides formadores de galha e de cisto patogênicos à cultura da soja em municípios do Oeste do Paraná. Nematologia Brasileira 29: 261-265.

FREITAS, VMS, JOELMA. GP; GOMES, CB; CASTRO, JMC; CORREA, VR; CARNEIRO, RMDG. 2016. Host status of selected cultivated fruit crops to Meloidogyne enterolobii. European Journal of Plant Pathology 147: 1-13.

GARCIA, ME; ERNST, T; JOHNSON, DT; DICKEY, DA. 2017. Strawberry cultivars performance in high tunnels under sustainable and organic production practices in three climatic regions of Arkansas. Acta Horticulturae Procedings of the VIII International Strawberry Symposium 2: 549-553.

GOMES, CB; COFCEWICZ, ET. 2003. Nematoides. In: FORTES, JF; OSORIO, VA. (org). Morango: fitossanidade. Brasília: Embrapa Informação Tecnológica; Pelotas: Embrapa Clima Temperado. p.19-22 (Frutas do Brasil. 41).

HUSSEY, RS; BARKER, KR. 1973. A comparison of methods of collecting inocula of Meloidogyne ssp. including a new technique. Plant Disease Reporter 57: 1025-1028.

LEMISKA, A; PAULETTI, V; CUQUEL, FL; ZAWADNEAL, MAC. 2014. Produção e qualidade da fruta do morangueiro sob influência da aplicação de boro. Ciência Rural 44: 622-628.

LIMA, EA; MATTOS, JK; MOITA, AW; CARNEIRO, RG; CARNEIRO, RMDG. 2009. Host status of different crops for Meloidogyne ethiopica control. Tropical Plant
Pathology 34: 152-157.

LIMA-MEDINA, I; GOMES, CB; CORREA, VR; MATTOS, VS; CASTAGNONE-SERENO, P; CARNEIRO, RMDG. 2017. Genetic diversity of Meloidogyne spp. parasitizing potato in Brazil and aggressiveness of Meloidogyne javanica populations on susceptible cultivars. Nematology 19: 69-80.

LIMA-MEDINA, I; GOMES, CB; GONZAGA, V. 2014. Caracterização de espécies do nematoide das lesões em batata na região sul do Brasil e reação de genótipos a Pratylenchus brachyurus. Nematropica 44: 101-106.

LOUBSER, JT; MEYER, AJ. 1987. Resistance of grapevine rootstocks to Meloidogyne incognita under field conditions. South African Journal of Enology and Viticulture 2: 70-74.

MAAS, JL. 1998. Compendium of strawberry diseases. 2ed. Minnesota: APS Press. St. Paul, 128p.

OMAIAA-OBSERVATÓRIO DOS MERCADOS AGRÍCOLAS E DAS IMPORTAÇÕES AGRO-ALIMENTARES. 2017. A produção e a comercialização do morango em Portugal. Available $<$ http://www.observatorioagricola. pt/item.asp?id_item $=104>$. Accessed on September 21, 2017.

OOSTENBRINK, M. 1966. Major characteristics of the relation between nematodes and plants. Wageningen: Mendelingen Landbouwhoge School 6: 1-46.

PINKERTON, J; FINN, CE. 2005. Responses of strawberry species and cultivars to the rootlesion and Northern root-knot nematodes. Hortscience 40: 33-38.

RIBEIRO, NR; DIAS, WP; SANTOS, JM. 2010. Distribuição de fitonematoides em regiões produtoras de soja do estado de Mato Grosso. Rondonópolis: Fundação MT. p.289-296. (Boletim de Pesquisa de Soja).

SEVERINO, JJ; DIAS-ARIEIRA，CR; TESSMANN, DJ. 2010. Nematodes associated with sugarcane in sandy soils in Paraná, Brazil. Nematropica 40: 111-119.

SHARMA, RD; FONSECA, CEL. 2000. Efeito de Meloidogyne javanica no crescimento da ervilha. Pesquisa Agropecuária Brasileira 35: 115-120.

SOMAVILLA, L; GOMES, CB; OLIVEIRA, RP; CARNEIRO, RMDG. 2006. Resistência de cultivares de morangueiro ao nematoide das galhas Meloidogyne ethiopica Whitehead. 1969. Nematologia Brasileira 30: 299-301.

VILLANUEVA, L; FLORES M; PEDROCHE, N. 2010. Response of six strawberry (Fragariax ananassa Duch.) cultivars to the root lesion nematode (Pratylenchus penetrans Filipjev and Schurmanns Stekhoven). Communications in Agricultural and Applied Biological Sciences 75: 487-496. 